\title{
Erratum to: Bone mineral density and vitamin D levels in erythropoietic protoporphyria
}

\author{
Gonzalo Allo • Maria del Carmen Garrido-Astray • \\ Manuel Méndez • Rafael Enríquez De Salamanca • \\ Guillermo Martínez $\cdot$ Federico Hawkins
}

Published online: 17 April 2013

(C) Springer Science+Business Media New York 2013

\section{Erratum to: Endocrine}

\section{DOI 10.1007/s12020-013-9934-x}

An author was omitted from the original publication. The author should appear third in the list, and his complete details are as follows: Manuel Méndez, Research Center, University Hospital 12 de Octubre, Madrid, Spain.

The online version of the original article can be found under doi: 10.1007/s12020-013-9934-x.

G. Allo · G. Martínez · F. Hawkins ( $\square)$

Endocrinology Service, University Hospital 12 de Octubre,

Avenida Córdoba S/N, 28026 Madrid, Spain

e-mail: fhawkins.hdoc@salud.madrid.org

M. del Carmen Garrido-Astray

Department of Morphological Sciences and Biomedicine,

European University of Madrid, Madrid, Spain

M. Méndez · R. E. De Salamanca

Research Center, University Hospital 12 de Octubre, Madrid,

Spain 